\title{
Novel Adsorption Method for Contaminated Water by Wild Endemic Almond: Amygdalus scoparia
}

\author{
Parisa Ziarati ${ }^{1,2}$ *, Fatemehsadat MirMohammad-Makki ${ }^{1,3}$ \\ and Maryam Moslehishad ${ }^{1}$
}

\author{
${ }^{1}$ Young Researchers \& Elite Club, Pharmaceutical Sciences Branch, \\ Islamic Azad University, (IAUPS), Tehran, Iran \\ ${ }^{2}$ Depatment of Medicinal Chemistry, Pharmacy Faculty, Pharmaceutical Sciences Branch, Islamic \\ Azad University (IAUPS), Tehran, Iran \\ ${ }^{3}$ Department of Food Sciences \& Technology, Faculty of Advanced Sciences \& Technology, \\ Pharmaceutical Sciences Branch, Islamic Azad University, Tehran, Iran (IAUPS) \\ http://dx.doi.org/10.13005/bbra/2017
}

(Received: 01 January 2016; accepted: 04 March 2016)

\begin{abstract}
Many of the water systems keep ecosystems thriving and feed a growing human population have become stressed. Water pollution especially heavy metal contamination is a major global problem and it is leading to deaths and diseases. In this study the potential of wild endemic almond: Amygdalus scoparia shell was assessed for adsorption of heavy metal ions such as $\mathrm{Pb}^{2+}, \mathrm{Ni}^{2+}, \mathrm{Cr}^{6+}$ and $\mathrm{Cr}^{3+}$ from aqueous solution. A. Scoparia fruits were collected in July 2014 from Sirmand Mountains near Hadji-Abad County, Hormozgan province and the mountains in Gnow protected area, Bandar-Abbas, Hormozgan province in Iran, respectively. Analyzing of $\mathrm{Pb}, \mathrm{Ni}$ and $\mathrm{Cr}$ (III) and $\mathrm{Cr}$ (VI) concentrations performed using Inductively Coupled Plasma-Atomic Emission Spectrometry (ICP-AES). Adsorption capacity of $\mathrm{Cr}$ (VI), $\mathrm{Cr}$ (III), $\mathrm{Pb}$ and $\mathrm{Ni}$ onto modified almond shells by phosphoric acid was investigated in a batch system by considering the effects of various parameters like contact time, initial concentrations, $\mathrm{pH}$, temperature, absorbent dose and particle size. The adsorption was $\mathrm{pH}$ solution dependent and the maximum adsorption was observed at solution $\mathrm{pH}$ of 3.23. Moreover, contents of different heavy metals in the contaminated water showed significant $(p<0.05)$ and positive correlation with contents of $\mathrm{Pb}(\mathrm{r}=+82$ to $\mathrm{r}=+96), \mathrm{Cr}^{6+}(\mathrm{r}=+74$ to $\mathrm{r}=+94), \mathrm{Cr}^{3+}(\mathrm{r}=$ +84 to $r=+98)$, Ni $(r=+33$ to $r=+42)$ in the wastewater and A. Scoparia modified shell, respectively. The amounts of $\mathrm{Cr}$ (VI) adsorbed increased significantly with increase in dose of A. scoparia adsorbent $(p<0.05)$ and their contact time $(p<0.05)$. The results of this study revealed that A. scoparia can accumulate high level of lead, Chrome (VI) and (III) in a short time and their uptake rate by plant is significantly affected by their concentrations in the contaminated water $(p<0.005)$. A contact time of 48 hours by almond shell was found to be optimum and $87.1 \% \mathrm{Cr}$ (VI), $89.8 \% \mathrm{Cr}$ (III), $84.4 \% \mathrm{~Pb}$ and 48.1\% $\mathrm{Ni}$ was removed. Experimental results showed that low cost bio-sorbent was effective for the removal of pollutants from aqueous solution.
\end{abstract}

Key words: Amygdalus scoparia, Contaminated Water, Adsorbent, Removal of Heavy Metals.

Nowadays one in seven people on our planet, lack access to safe drinking water. More than 40 percent of the planet's population will be living in areas of "severe" water stress and around

\footnotetext{
* To whom all correspondence should be addressed. Tel: +98-21-22600037; Fax: +98-21-22633986; E-mail: ziarati.p@iaups.ac.ir
}

768 million people do not have access to a safe, reliable source therefore water pollution has become to a major global problem and it is leading worldwide cause of deaths and diseases. Pollution of the biosphere with toxic metals has accelerated dramatically since the beginning of the Industrial Revolution ${ }^{1-3}$. Wetland is a water environment which has considerable scientific, economic and 
social values. They are the habitats of various organisms contributing to the gene cache of microbes, plants and animals on the earth. However, nowadays the pollution and degradation of the wetlands are increasing dramatically ${ }^{4}$. Marine animals can accumulate metals through sea water, suspended particles, sediments and food chains ${ }^{5}$. Permanent contaminants such as metals may be transferred to higher levels in the food chain through environmental expansion. Behavior of trace elements in various weathering environments is dramatically different. In world soil neutral or alkaline weathering environments, $\mathrm{U}, \mathrm{V}$, Mo, and $\mathrm{Zn}$ have high mobility, while $\mathrm{Mn}, \mathrm{Pb}, \mathrm{Ba}$, $\mathrm{Be}$, and $\mathrm{Bi}$ have low mobility, and $\mathrm{Cu}, \mathrm{Co}, \mathrm{Fe}, \mathrm{Ni}$, Th, Y have very low mobility. Otherwise, in reducing environment conditions $\mathrm{As}, \mathrm{Ba}, \mathrm{Be}, \mathrm{Bi}$, $\mathrm{Cd}, \mathrm{Co}, \mathrm{Cu}, \mathrm{Mo}, \mathrm{Ni}, \mathrm{Pb}, \mathrm{Se}, \mathrm{Th}, \mathrm{U}, \mathrm{Zn}, \mathrm{V}$, and Y have a very low degree of mobility 6 . Trivalent chromium occurs widely in nature and is an essentials nutrient required by the human body to promote the action of insulin in body tissues. Chromium as a pure metal has no reported human or environmental toxicity effects. Both acute and chronic toxicity of chromium are mainly caused by hexavalent chromium compounds (Cr VI). Hexavalent chromium is considered the most hazardous of all forms, and in welding fume it is a suspected human carcinogen. DNA damage in welders has been associated with hexavalent chromium exposure ${ }^{7}$. This is consistent with the classification of hexavalent chromium as a human lung carcinogen ${ }^{8}$.

Many agricultural by-products such as almond and other fruit or nut shells are available and have low cost. Almond (Rosaceae family) with wide applications in pharmaceutical, oleo chemicals, food and cosmetic industries is considered as a pleasant nut throughout the world. Other than the regular almond, there are more than thirty wild or partially cultivated almond species in the world of which twenty species have been reported in $\operatorname{Iran}^{1,9}$. Iran is the main center for distribution of genus Amygdalus. L . Amygdalus is one of the most problematic genera in family Rosaceae and taxonomy of this genus like many other genera in this family with numerous problems because of high degree of variation in morphological conditions ${ }^{10}$. (Khatamsaz 1993).It shows high degree of variation within one species, high hybridization inter species and high homoplasy under ecological conditions11.

As Iran is one of the richest countries in the world as regards genetic resources of medicinal and wild unknown plants that some of them are export ${ }^{12}$. We have studied on potential ability of Amygdalus specie as this endemic specie found in some parts of Iran especially in south regions due to accumulate Chrome and Nickel as the major concern in wetland pollution.

\section{MATERIALSANDMETHODS}

\section{Study of Area}

Almond in areas with warm, dry summers and cold winters and short fall grows well. Distribution Almond mountain areas in Zagros foothills of khuzestan begins and in altitudes 600 to 1500 meters above sea level is located (Figure 1). Around the city of Dezful, Izeh, Baghmalek, Masjed Soleiman and Haftgol abundant of almond can be seen [13]. The Izeh fault zone is a transverse fault zone with dextral strike slip (and some reverse component) in the Zagros Mountains (Iran). It causes some structural deformations. This fault zone is acting as eastern boundary of Dezful Embayment and forms subsidence of the embayment ${ }^{13}$. The Type of regional climate is related to the dry forests and minimum temperature of $18.11^{\circ} \mathrm{C}$ and the average temperature of $23^{\circ} \mathrm{C}$ and the maximum temperature are $48.5^{\circ} \mathrm{C}$.

Shell samples were washed several times with deionized water and dried (sun or mechanical). The adsorbents were then ground in a blender and stored for further use. All reagents and chemicals were used of analytical reagent grade and were obtained from standard sources.

Phosphoric acid, activated carbon, potassium dichromate and other chemicals were obtained from standard sources.

\section{Characteristics of wastewater}

To move forward on chemicals management, a project has been done in Pharmaceutical faculty in Tehran-Iran which has 20 laboratories in chemical and toxicological laboratories whose area of work are divided into two types of educational and research. The research has focused on comprehensive environmental management of the poisonings and exposure to toxic and hazardous chemicals especially Lead, Nickel and $\mathrm{Cr}$ (III) and $\mathrm{Cr}$ (VI). The 
wastewater of inorganic research laboratory was collected during 2 weeks in summer 2015. The samples were collected ten days before the experiment. They were in sterile plastic bottle and were transported to laboratory and kept in $25 \mathrm{C}^{0}$.

\section{Experimental design and Chemical analysis}

The shell part of A. scoparia was soaked in phosphoric acid $2 \%$ for 24 hours and then dried at $80{ }^{\circ} \mathrm{C}$ in an oven for 24 hours [6,7, 25-29 ]. Dry parts were then ground and passed through standard steel sieves (72 mm mesh size). The fine powder was used without washing or any other physical or chemical treatments. The amount of adsorbent was kept constant as 0.5 gram in all the combinations. Adsorbent was added to $100 \mathrm{ml}$ waste water contained heavy metal solutions. The sorption studies were carried out at $25 \pm 1^{\circ} \mathrm{C}$ till 60 hours and in every 10 hours they were studied . A metal and biomass free blank was used as control. The mixtures were filtered through filter paper (pore diameter 11ìm) and metal concentrations were determined by Inductively Coupled Plasma-Atomic Emission Spectrometry (ICP-AES).

Metal removal (\%) at any instant of time was determined by the following equation:

Heavy metal removal $(\%)=(\mathrm{Ci}-\mathrm{Cf}) / \mathrm{Ci}$ X 100

Where, $\mathrm{Ci}$ and $\mathrm{Cf}$ represent initial and final metal concentration $(\mathrm{mg} / \mathrm{L})$ at any instant of time, respectively

Shell samples after being used as adsorption and wastewater treated samples after being objected by A. scoparia modified shell were studied with concentrated $\mathrm{HNO}_{3}$ and $\mathrm{H}_{2} \mathrm{O}_{2}$, due to find out the potential of adsorbing heavy metals. The digested solution was filtered and then analyzed for $\mathrm{Pb}, \mathrm{Ni}$ and $\mathrm{Cr}$ (III) and $\mathrm{Cr}$ (VI), concentration using Inductively Coupled PlasmaAtomic Emission Spectrometry (ICP-AES) (Varian 730-ES Axial ICPOES: USA).

$\mathrm{pH}$ of wastewater samples before and after being treated by A. scoparia adsorbent were determined. The $\mathrm{pH}$ of samples was measured by potentiometer (Inolab, Weilheim, Germany) after calibration using standard buffers pH 6.0 and 9.0. The $\mathrm{pH}$ was recorded after the $\mathrm{pH}$ meter provided final reading.

\section{Statistical analysis}

The values reported here are means of six values. Data were tested at different significant levels using student t-test to measure the variations between the wastewater parameters before and after treated by A. scoparia modified shell with wastewater. One way analysis of variance (OneANOVA) was used for data analysis to measure the variations of metal concentrations using SPSS 22.0 software (SPSS Inc, IBM, Chicago, IL).

\section{RESULTS}

The mean \pm SD values of various physicochemical and heavy metal characteristics of control (untreated waste water) and treated wastewater are presented in Table 1 . The results revealed that wastewater contained significant quantity of nutrients like $\mathrm{Na}^{+}, \mathrm{K}^{+}, \mathrm{Ca}^{2+}, \mathrm{Mg}^{2+}, \mathrm{TKN}, \mathrm{PO}_{4}^{3-}, \mathrm{SO}_{4}^{2-}$ and heavy metals such as $\mathrm{Cd}, \mathrm{Cr}, \mathrm{Cu}, \mathrm{Fe}, \mathrm{Mn}, \mathrm{Pb}$ and $\mathrm{Zn}$. These are very important parameters that lead to water and soil contamination. The values of various wastewater characteristics like TDS (2860.00 $\mathrm{mg} \mathrm{L}^{-1}$ ), BOD (1450.30 $\mathrm{mg} \mathrm{L}^{-1}$ ), COD (3225.00 $\left.\mathrm{mg} \mathrm{L}^{-1}\right), \mathrm{Ca}^{2+}\left(650.90 \mathrm{mg} \mathrm{L}^{-1}\right)$, TKN (420.70 $\left.\mathrm{mg} \mathrm{L}^{-1}\right)$, Cu (10.36 $\left.\mathrm{mg} \mathrm{L}^{-1}\right)$, Fe (16.84 $\left.\mathrm{mg} \mathrm{L}^{-1}\right)$, Mn (6.67 $\mathrm{mg} \mathrm{L}^{-1}$ ), Pb (9.64 mg L $\left.{ }^{-1}\right)$, Zn (18.66 mg L ${ }^{-1}$ ), SPC $\left(7.68 \times 10^{8} \mathrm{SPC} \mathrm{ml}^{-1}\right)$ and MPN $\left(8.69 \times 10^{5} \mathrm{MPN}\right.$ $100 \mathrm{ml}^{-1}$ ) were recorded beyond the prescribed BIS standards of irrigation water (Table 1). The higher TDS in the wastewater is likely due to the occurrence of feacal matter while the more BOD and COD are associated with the presence of higher biodegradable organic waste in the wastewater. The higher number of SPC and MPN in the wastewater are the indicator of feacal pollution and pathogens. TKN and $\mathrm{PO}_{4}{ }^{3-}$ were also recorded higher in the wastewater and are associated with eutrophication of aquatic ecosystems. Therefore, various parameters clearly indicated that the wastewater was highly rich in plant nutrients, heavy metals and contagious.

\section{Chemical analysis}

Experimental results showed that the percentage removal Cr (VI) increases with the increasing amount of adsorbent up to $5.4 \mathrm{~g}$ for treated shells by phosphoric acid 2\%. After this dose of adsorbent no significant change was observed, but for untreated almond shells percentage removal $\mathrm{Cr}$ (VI) increases with the increasing amount of adsorbent.

Metal accumulation in shells increased significantly with an increase in applied metal solution concentration in both lead (figure 2) and 
Table 1. Physico-chemical and heavy metal characteristics of control (untreated wastewater ) and treated wastewater by A. scoparisa shells after 60 hours

\begin{tabular}{|c|c|c|c|}
\hline Parameters & $\begin{array}{l}\text { Untreated } \\
\text { wastewater by } A \\
\text {. Scoparia shell }\end{array}$ & $\begin{array}{l}{ }^{\text {a }} \text { Treated } \\
\text { wastewater } \\
\text { water by A. } \\
\text { Scoparia Shell }\end{array}$ & $\begin{array}{l}\text { BIS for } \\
\text { irrigation } \\
\text { water }\end{array}$ \\
\hline TDS( $\left.\mathrm{mg} \mathrm{L}^{-1}\right)$ & $2920.00 \pm 5.80$ & ${ }^{* * *} 180.50 \pm 3.64$ & 1900 \\
\hline $\mathrm{EC}\left(\mathrm{dS} \mathrm{m}^{-1}\right)$ & $4.50 \pm 1.05$ & $0.12 \pm 0.10$ & - \\
\hline $\mathrm{pH}$ & $6.92 \pm 0.55$ & ${ }^{\mathrm{NS}} 6.85 \pm 0.36$ & $5.5-9.0$ \\
\hline $\mathrm{BOD}\left(\mathrm{mg} \mathrm{L}^{-1}\right)$ & $1450.30 \pm 7.88$ & ${ }^{* * *} 4.20 \pm 0.70$ & 100 \\
\hline $\mathrm{COD}\left(\mathrm{mg} \mathrm{L}^{-1}\right)$ & $3436.00 \pm 6.00$ & ${ }^{* * *} 6.32 \pm 1.80$ & 250 \\
\hline $\mathrm{Na}^{+}\left(\mathrm{mg} \mathrm{L}^{-1}\right)$ & $286.95 \pm 4.20$ & ${ }^{* * *} 10.60 \pm 1.15$ & - \\
\hline $\mathrm{K}^{+}\left(\mathrm{mg} \mathrm{L}^{-1}\right)$ & $380.70 \pm 3.57$ & ${ }^{* * *} 6.33 \pm 1.40$ & - \\
\hline $\mathrm{Ca}^{2+}\left(\mathrm{mg} \mathrm{L}^{-1}\right)$ & $650.90 \pm 4.65$ & ${ }^{* * *} 28.95 \pm 2.30$ & 200 \\
\hline $\mathrm{Mg}^{2+}\left(\mathrm{mg} \mathrm{L}^{-1}\right)$ & $266.44 \pm 3.73$ & ${ }^{* *} 18.76 \pm 2.65$ & - \\
\hline TKN (mg L $\left.{ }^{-1}\right)$ & $562.56 \pm 2.89$ & ${ }^{* * *} 33.18 \pm 3.76$ & 100 \\
\hline $\mathrm{PO}_{4}^{3-}\left(\mathrm{mg} \mathrm{L}^{-1}\right)$ & $120.68 \pm 1.28$ & ${ }^{* * *} 0.33 \pm 0.06$ & - \\
\hline $\mathrm{SO}_{4}^{4-}\left(\mathrm{mg} \mathrm{L}^{-1}\right)$ & $923.11 \pm 2.85$ & ${ }^{*} 168.94 \pm 2.80$ & 1000 \\
\hline $\mathrm{Cd}\left(\mathrm{mg} \mathrm{L}^{-1}\right)$ & $2.86 \pm 0.06$ & ${ }^{* * *} 0.13 \pm 0.03$ & 2 \\
\hline $\mathrm{Cr}\left(\mathrm{mg} \mathrm{L}^{-1}\right)$ & $11.24 \pm 0.02$ & ${ }^{* * *} 1.02 \pm 0.01$ & 2 \\
\hline $\mathrm{Cu}\left(\mathrm{mg} \mathrm{L}^{-1}\right)$ & $10.36 \pm 1.05$ & ${ }^{* *} 2.64 \pm 0.12$ & 3 \\
\hline $\mathrm{Fe}\left(\mathrm{mg} \mathrm{L}^{-1}\right)$ & $16.84 \pm 1.15$ & ${ }^{*} 3.85 \pm 0.04$ & 1 \\
\hline $\operatorname{Mn}\left(\mathrm{mg} \mathrm{L}^{-1}\right)$ & $6.67 \pm 1.04$ & ${ }^{* * *} 0.48 \pm 0.06$ & 1 \\
\hline $\mathrm{Ni}\left(\mathrm{mg} \mathrm{L}^{-1}\right)$ & $3.18 \pm 0.02$ & ${ }^{*} 1.08 \pm 0.04$ & 0.2 \\
\hline $\mathrm{Pb}\left(\mathrm{mg} \mathrm{L}^{-1}\right)$ & $10.47 \pm 3.28$ & ${ }^{* * *} 0.81 \pm 0.03$ & 1 \\
\hline $\mathrm{Zn}\left(\mathrm{mg} \mathrm{L}^{-1}\right)$ & $24.49 \pm 1.11$ & $* 7.08 \pm 2.03$ & 15 \\
\hline $\mathrm{SPC}\left(\mathrm{SPC} \mathrm{ml}^{-1}\right)$ & $8.67 \times 10^{8} \pm 13$ & ${ }^{* *} 1.84 \pm \times 10^{3} \pm 3$ & 10000 \\
\hline MPN(MPN100 ml -1) & $9.11 \times 10^{5} \pm 10$ & ${ }^{* *} 2.88 \times 10^{2} \pm 11$ & 5000 \\
\hline
\end{tabular}

Mean \pm SD of six values; a treated wastewater. Significant - ${ }^{* * *} \mathrm{p}>0.1$ level: ${ }^{* *} \mathrm{p}>0.01 \%$ level; *p>0.05 level; NS-not significant.

$\mathrm{Cr}$ (III) and $\mathrm{Cr}$ (VI), (Figures 3 and 4 respectively) treated groups. In Figures 2, 3 and 4 the mean contents of heavy metals are reported. The metal concentrations remained high in shells in $\mathrm{Cr}$ (III) and $\mathrm{Cr}(\mathrm{VI})$, treated groups, while lead metal content was higher in treated shells than untreated shells. The ratios of shells/water ratios were calculated to indicate the translocation efficiency of $\mathrm{Pb}$ and $\mathrm{Cr}$ from water to the adsorbents while for the results of nickel translocation was not significant. The $\mathrm{Cr}$ (III) concentrations in samples after 10, 20, 30 and 40 hours are higher in shells than $\mathrm{Cr}(\mathrm{VI})$, hence the translocation factor ratios were less than one for $\mathrm{Cr}(\mathrm{VI})$ treated samples shows that this method is highly suitable for adsorbing $\mathrm{Cr}(\mathrm{III})$ to the $\mathrm{Cr}$ (VI). Even though the $\mathrm{Cr}(\mathrm{VI})$, concentration of shells of Cr treated samples in 48 hours treated samples is higher compared to controls solutions, the extent of metal accumulation and uptake efficiency of $\mathrm{Cr}(\mathrm{III})$ was lower than that of $\mathrm{Cr}(\mathrm{VI})$, in long term contaminated situation study. Most of shells in $\mathrm{Cr}$ (VI) samples deformed after 60 hours remaining in contaminated water. The effect of

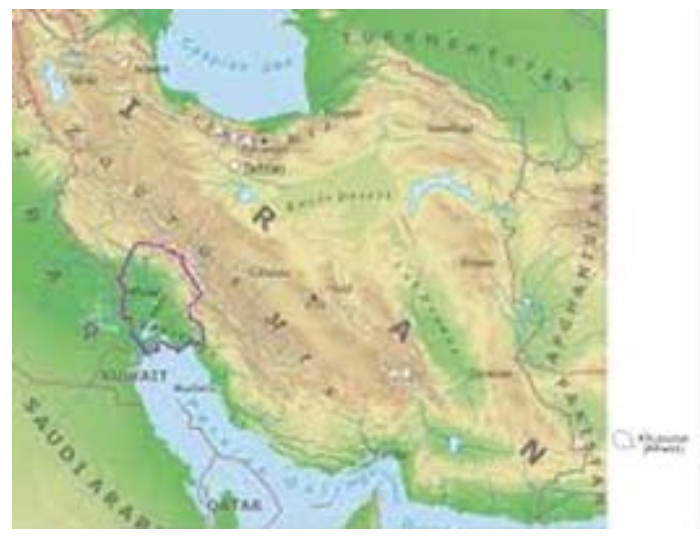

Fig. 1. Location of Amygdalus scoparia sampling collection 


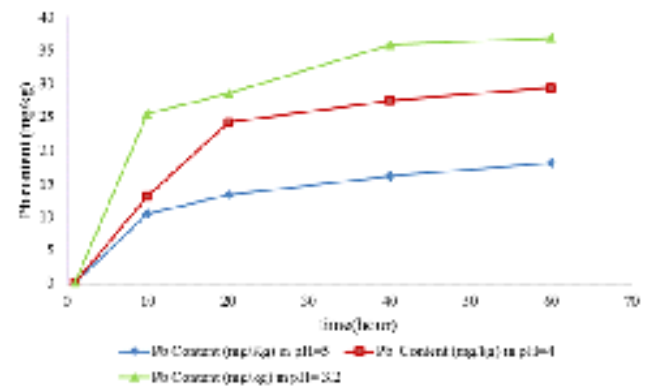

Fig. 2. The mean content of Lead $\left(\mathrm{mg} \mathrm{kg}^{-1}\right)$ in A. Scoparia treatment groups in contaminated 100 , 200 and $300 \mathrm{mg} \mathrm{kg}^{-1}$ Lead solution in the form of $\mathrm{Pb}\left(\mathrm{NO}_{3}\right)_{2}$ in different $\mathrm{pH}$ and contact times (hours)

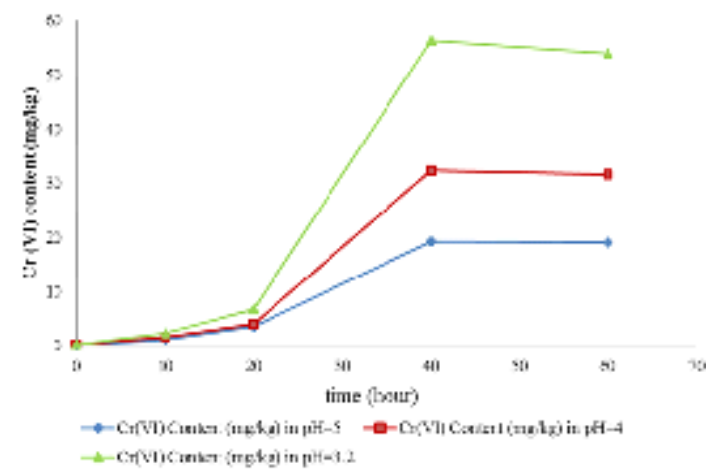

Fig. 4. The mean content of $\mathrm{Cr}(\mathrm{VI})\left(\mathrm{mg} \mathrm{kg}^{-1}\right)$ in A. Scoparia treatment groups in contaminated 100, 200 and $300 \mathrm{mg} \mathrm{kg}^{-1}$ Chrome (+6) solution in the form of $\mathrm{Cr}\left(\mathrm{NO}_{3}\right)_{6}$ in different $\mathrm{pH}$ and contact times (hours)

adsorbent dose on Cr (VI) uptake was investigated by varying the shell adsorbent dose (1, 2, 3, 4 and $6 \mathrm{~g} 100 \mathrm{ml}^{-1}$ ) for a time interval of 0 - 60 hours min (Figure-4).

\section{DISCUSSION}

The results of present study revealed adsorption capacity of $\mathrm{Cr}$ (VI), $\mathrm{Cr}$ (III), $\mathrm{Pb}$ and $\mathrm{Ni}$ onto modified almond shells by phosphoric acid was investigated in a batch system by considering the effects of various parameters like contact time, initial concentrations, $\mathrm{pH}$, temperature, absorbent dose and particle size. The adsorption was $\mathrm{pH}$ solution dependent and the maximum adsorption was observed at solution $\mathrm{pH}$ of 3.23. Moreover, contents of different heavy metals in the contaminated water showed significant $(p<0.05)$ and positive correlation with contents of $\mathrm{Pb}(\mathrm{r}=$

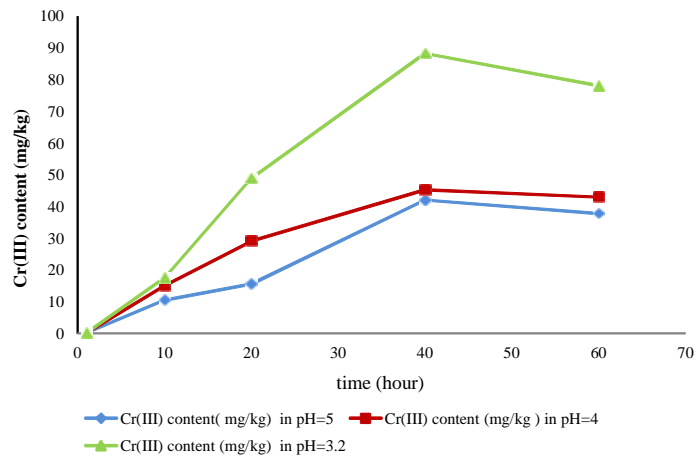

Fig. 3. The mean content of $\mathrm{Cr}(\mathrm{III})\left(\mathrm{mg} \mathrm{kg}^{-1}\right)$ in A. scoparia treatment groups in contaminated 100 , 200 and $300 \mathrm{mg} \mathrm{kg}^{-1}$ chrome solution in the form of $\mathrm{Cr}\left(\mathrm{NO}_{3}\right)_{3}$ in different $\mathrm{pH}$ and contact times (hours)

+82 to $\mathrm{r}=+96), \mathrm{Cr}^{6+}(\mathrm{r}=+74$ to $\mathrm{r}=+94), \mathrm{Cr}^{3+}(\mathrm{r}=+84$ to $r=+98)$, $\mathrm{Ni}(\mathrm{r}=+33$ to $\mathrm{r}=+42)$ in the wastewater and A. Scoparia modified shell, respectively. The amounts of $\mathrm{Cr}$ (VI) adsorbed increased significantly with increase in dose of A. scoparia adsorbent $(p<0.05)$ and their contact time $(p<0.05)$. The results of this study revealed that A. scoparia can accumulate high level of lead, Chrome (VI) and (III) in a short time and their uptake rate by plant is significantly affected by their concentrations in the contaminated water $(p<0.005)$. A contact time of 48 hours by almond shell was found to be optimum and 87.1\% Cr (VI), 89.8\% Cr(III), 84.4\% $\mathrm{Pb}$ and $48.1 \% \mathrm{Ni}$ was removed. Experimental results showed that low cost bio-sorbent was effective for the removal of pollutants from aqueous solution.

According to ATSDR, current evidences indicate that $\mathrm{Cr}$ (VI) is a cancer agent only by inhalation. Chronic inhalation studies on mice exposed to airborne $\mathrm{Cr}$ (VI) suggest that $\mathrm{Cr}$ (VI) is an animal carcinogen ${ }^{14-15}$. The mice developed lung tumors from exposure to $4.3 \mathrm{mg} \mathrm{m}^{3}$ of $\mathrm{Cr}(\mathrm{VI})$.However, a number of chronic animal studies showed no carcinogenic effects in rats, rabbits, or guinea pigs exposed to $1.6 \mathrm{mg} / \mathrm{m} 3$ of $\mathrm{Cr}(\mathrm{VI})^{14-17}$. Thus, cancer effects on animals seem to depend on the type of animal. Eating small amounts of chromium (VI) is not harmful. However, eating or drinking large amounts in food or water can cause an upset stomach, ulcers, convulsions, and damage the kidneys and liver. This type of exposure can be fatal. There is not enough data to know if eating or drinking chromium (VI) causes cancer ${ }^{14-17}$. The results of this study revealed that $A$. scoparia 
can accumulate high level of Chrome (VI) and (III) in a short time and their uptake rate by plant is significantly affected by their concentrations in the contaminated water $(p<0.005)$.

\section{CONCLUSION}

The present investigation shows that the almond shells are effective and inexpensive biosorbents for the removal of $\mathrm{Cr}(\mathrm{VI})$ from aqueous solutions. The removal of $\mathrm{Cr}(\mathrm{VI})$ from aqueous solutions strongly depends on the contact time, initial concentration, $\mathrm{pH}$, temperature, agitation speed, absorbent dose and particle size. The amounts of $\mathrm{Cr}$ (VI) adsorbed increased with an increase in dose of both adsorbents and their contact time. A contact time of 48 hours was found to be optimum. The maximum adsorption capacity was obtained at solution $\mathrm{pH}$ of 3.2.

A contact time of 48 hours by almond shell was found to be optimum for Nickel adsorbing and $48.1 \% \mathrm{Ni}$ was removed. Although $\mathrm{Ni}$ is required in minute quantity for body as it is mostly present in the pancreas and hence plays an important role in the production of insulin. EPA has recommended daily intake of Ni should be less than $1 \mathrm{mg}$ beyond which is toxic ${ }^{17}$. Ni has been identified as a suspected carcinogen and adversely affects lungs and nasal cavities ${ }^{18}$.

This research conduct adsorption of heavy metals by agricultural waste and by-product and proved that this friendly method should gain more attention and research interest for the removal of heavy metals from waste water due to its surface area, adsorption capacity and plenty abundant in nature must be followed seriously.

Also, this research suggests more investigations by other genera and families of costeffective waste agricultural products applying as adsorbents for these heavy metals and other toxic metals such as cadmium, arsenic and Mercury.

\section{ACKNOWLEDGMENTS}

Pharmaceutical Sciences Branch, Islamic Azad University (IAUPS) is gratefully acknowledged.

\section{REFERENCES}

1. Nriagu, J.O. Global inventory of natural and anthropogenic emission of trace metals to the atmosphere. Nature J., 1979; 279: 409-411.

.2 Sayyed, M.R.G., Sayadi, M.H. Variations in the heavy metal accumulations within the surface soils from the Chitgar industrial area of Tehran. Proceedings of the International Academy of Ecology and Environmental Sciences., 2011; 1(1) :36-46.

3. Seifi-Nigje Gheshlagh, F., Ziarati, P., Arbabi Bidgoli, S. Seasonal fluctuation of heavy metal and nitrate pollution in ground water of farmlands in Talesh Gilan, Iran. International Journal of Farming and Allied Sciences. 2013; 2(20): 836841.

4. Dadgar, S., Teimoori, B., Yousefi, S., Tabatabaei, M. Determination of PCB levels in skin and muscle of northern pike (Esox lucius) in Anzali Wetland, Iran. Annals of Biological Research ., 2014; 1: 112-117.Available in site: http:// www.scholarsresearchlibrary.com.

5. Saghali, M., Baqraf, R., NejatkhahManavi, P., Abbas Hosseini, S., Patymar, R. Assignment of Concentration of Heavy Metals (Cr, Zn, Cd, $\mathrm{Pb}$ ) In Sediments of Gorgan Bay and South East the Caspian sea (Golestan Province- Iran). Environment and Ecology Research., 2013; 1(2): 27-31. Available in Site: http://www.hrpub.org/ download/201309/eer.2013.010201.pdf.

6. Abbaslou, H., Martin, F., Abtahi, A., Moore,F.. Trace element concentrations and background values in the arid soils of Hormozgan Province of southern Iran, Archives of Agronomy and Soil Science, . 2014; 60(8): 1125-1143. Available online: http://dx.doi.org/10.1080/ 03650340.2013.864387).

7. Sellappa, S.; Prathyumnan, S.; Keyan, K.S.; Joseph, S.; Vasudevan, B.S.; Sasikala, K. Asian Pac. J. Cancer Prev., 2010;11(1): 95-100.

8. U.S. Department of Health and Human Services. Report on carcinogens. Twelfth edition, Public Health Service, National Toxicology Program; 2011.

9. Kermanshah, A., Ziarati,P., Asgarpanah,J., Qomi, M. Food values of two endemic wild almond species from Iran. International Journal of Plant, Animal and Environmental Sciences. 2014; 4(3): 380-388.

10. Khatamsaz, M. Rosaceae. In: Flora of Iran . 1992; 6. Research Institute of Forests and Rangelands Publication, Tehran, Iran (in 
Persian)

11. Sayadi, Z., Taheri Abkenar, K., Salehi, A., Ebrahimi, A. An evaluation of the morphologic variety of Amygdalus schoparia branches in Qazvin province, Iran (Case study: Abyek town). European Journal of Experimental Biology, 2012; 2 (5):1685-1692.

12. Yousefia, M., Olyaei Juybari, E., Yahyapor, M.K., Dehpour, A. A. , Hoseinzade, M. Brine shrimp lethality activity of land and fresh water Medicinal Plants. Advances in Environmental Biology, 2012; 6(3): 1196-1199.

13. Safari, H., Pirasteh, S., Pradhan, B. . Upliftment Estimation of the Zagros Transverse Fault in Iran using Geoinformatics Technology. Remote Sens. 2009; 1: 1240-1256. doi:10.3390/ rs1041240.

14. Agency for Toxic Substances and Disease Registry (ATSDR), 2000, Toxicological Profile for Chromium, U.S. Department of Health and Human Services, Public Health Service, ATSDR, September 2000.

15. Office of Environmental Health Hazard Assessment (OEHHA), 2001, Public Health Goal (PHG) of $2.5 \mathrm{mg} / \mathrm{l}$ for $\mathrm{Cr}(\mathrm{VI})$ in Drinking Water is Withdrawn.

16. Mance, G. Pollution Threat of Heavy Metals in Aquatic Environment, Elsevier Applied Sciences, New York, NY, 1987; 372.

17. Ziarati ,P . Determination of Contaminants in Some Iranian Popular Herbal Medicines. $J$ Environment Analytic Toxicol., 2012; 2: 120. doi:10.4172/2161-0525.1000120.

18. Ziarati, P., Behbahani, P., Karbalei Mohammad, N. Role of Unprofessional storage methods on heavy metal contents on Rosa Damascena ( Gole Mohammadi). Journal of Pharmaceutical and Health Sciences .2012;1(4): 73-78. 